\title{
Topical advances and recent studies in paleolimnological research
}

\author{
Thomas J. WHITMORE, ${ }^{*}$ Melanie A. RIEDINGER-WHITMORE \\ Department of Biological Sciences, University of South Florida St. Petersburg, St. Petersburg, FL 33701 USA \\ *Corresponding author: whitmore@usfsp.edu
}

\begin{abstract}
Paleolimnology combines the disciplines of limnology, geology and ecology, but because of challenges that separate investigators from direct knowledge about past lake conditions, the field is multidisciplinary by necessity. As a result, paleolimnology is influenced continuously by advances in many disciplines. As with limnological studies in recent decades, paleolimnology has diverged largely from the ecological and theoretical focuses of early investigators, but recent studies demonstrate the need for more integration of ecological and paleolimnological research. This paper provides a brief overview of recent paleolimnological investigations that have addressed questions related to theoretical ecology, as well as applied lake-management and climate research issues. We examine the use of transfer function models for estimating past water-quality conditions, and important caveats expressed by investigators about limitations in the development and use of such models. Paleolimnological research has contributed new insights about biological, physical and chemical processes in lakes that have been subject to change because of climate drivers and anthropogenic influences. These findings are relevant to predicting how lakes will respond to climate change, and will require new management approaches in the future. As the range of paleolimnological studies expands, there will be greater need for basic limnological research in order for paleolimnological investigators to better understand how sediments reflect lake processes of those regions.
\end{abstract}

Key words: paleolimnology, limnology, lake sediments, climate change, theoretical ecology.

Received: June 2013. Accepted: November 2013.

\section{INTRODUCTION}

Paleolimnology is a discipline that is closely related to modern limnology. It involves the study of freshwater and some saline ecosystems in the context of long time sequences that are recorded in sediments. Sediment records reveal changes in limnological conditions that arose during the past because of natural succession, or because of climatic and human influences. Virtually all biological, chemical and physical processes that are studied in limnology leave evidence in sediments, but sedimentary records are subject to information loss because of many factors, including those that affect variable distribution of sedimentary constituents and post-depositional changes (Cohen, 2003).

Paleolimnological studies typically are deductive, and investigators are separated from direct knowledge of past limnological states by time and the effects of diagenesis. Limnological studies can satisfactorily examine one or few lines of evidence depending on their objectives, but in the historical context, individual lines of evidence are often subject to divergent interpretations. As a consequence, paleolimnology relies on interdisciplinary approaches to compensate for information loss, and to resolve the complexity of differential interpretations about ecosystem changes and driving forces. It is a tenet of paleolimnology that only hypotheses that explain all sets of data can be regarded as true (Pennington, 1981), so many lines of investigation typically are drawn upon to yield robust and defensible conclusions. The interdisciplinary nature of paleolimnological studies is reflected in frequent use of the term multiproxy in published papers, and that use is so common now that the term is trite. Because of its collaborative nature, paleolimnology is influenced continually by advances in many disciplines.

This paper provides a brief overview of various recent developments in the field of paleolimnology. Paleolimnological advances have been addressed in recent collected works (Pienitz et al., 2009) and in reviews on specific methodologies or topics (Leng and Henderson, 2013). The present paper is intended to complement those treatments and is written for the broader interests of the Journal of Limnology readers. We are pleased to offer this review on the special occasion of the $75^{\text {th }}$ anniversary of the Institute of Ecosystem Study (CNR-ISE Istituto per lo Studio degli Ecosistemi) in Verbania Pallanza, Italy.

\section{Ecological questions and theoretical studies}

In the rationale for the present volume, the editors observed that modern limnological studies have diverged from the fundamental ecological focus of prominent early limnologists. They noted that much could be done to use lakes as model systems to address advanced ecological questions using the accumulated body of knowledge and contemporary tools. In a similar manner, many paleolim- 
nological studies have become less theoretical and have focused on fewer topics that are more applied. Since the 1980 s, the subjects of most paleolimnological studies have been: i) lake-management questions, and how to document, quantify and correct anthropogenic perturbations such as eutrophication, lake acidification, and comtaminant deposition, and ii) climate change, and how to document and quantify the human component, and distinguish it from natural cycles and processes. These topics became the focus of research and funding mostly after it seemed evident that humans are responsible for substantially disrupting natural cycles, and a large proportion of contemporary papers address how to distinguish human influences from pre-disturbance conditions and natural processes. Paleolimnology is often the only means to assess environmental changes and their causes when longterm instrumental data are lacking (Smol, 2010).

Few contemporary paleolimnological studies examine biological remains out of direct interest for the organisms, and many studies describe biological and other forms of evidence using the term proxy, viewing them mostly as indirect measures for water-quality variables or processes that often pertain to applied questions. A proxy, in proper usage, is a substitute for a direct measurement or observation, but the term is so overused or generally applied that it's often not clear what variables are being referred to, or for what variables the proxies supposedly provide indirect measurement. The term could be used with more restraint, and its overuse reflects a tendency to view organisms as indicators of environmental conditions rather than subjects of study in themselves. While studies that address theoretical ecology or evolutionary biology (Decaestecker et al., 2007) hold considerable interest, a greater proportion of recent studies have been applied.

Some recent studies have continued to address theoretical ecological questions. In an important recent paper, Sayer et al. (2010c) discussed the need to combine paleolimnological methods with contemporary ecological studies to improve our understanding about changes in freshwater ecosystems. The authors demonstrated how misinterpretation of environmental change can occur when a single quantitative variable is inferred. To advance paleolimnological approaches, they advocated for integrated studies of biological groups, with improved knowledge of community and species ecology. Sayer et al. concluded that contemporary field studies, lake surveys, and experiments should be combined more often with paleolimnological studies to promote more reliable conclusions about population- and community-level changes. The authors stated:

Recently, palaeolimnology has largely been pre-occupied with developing transfer functions which use surface sediment-lake environment datasets to reconstruct a single environmental variable. Such models ignore complex controls over biological structure and can be prone to considerable error in prediction. Furthermore, by reducing species assemblage data to a series of numbers, transfer functions neglect valuable ecological information on species' seasonality, habitat structure and food web interactions. ... Palaeolimnological techniques can track long-term dynamics in lakes whilst smoothing out short-term variability and thus provide a unique and important means of not only developing ecological theories, but of testing them.

A long-held perception about ecosystem shifts between macrophyte and algal dominance is that they represent an abrupt change to an alternative stable state (Scheffer et al., 1993), with a brief, unstable intermediate state. In a modern survey of 39 lakes with seasonally stable or crashing macrophyte populations, Sayer et al. (2010b) showed that community compositional changes and decreased macrophyte diversity were associated with prolonged seasonal phytoplankton blooms. In a subsequent study that addressed stable-state ecological theory, Sayer et al. (2010a) examined plant macrofossil remains, pollen, and diatoms in six sediment cores from a transect across shallow Felbrigg Hall Lake (UK), and they performed an elegant spatial and temporal reconstruction of macrophyte presence and abundance over time. The authors noted that with progressive eutrophication, macrophyte diversity and the number of plant seasonal strategies declined, eventually enabling phytoplankton to outcompete macrophytes during increasingly widening gaps in seasonal macrophyte dominance. Rather than resulting from an abrupt system perturbation, this study demonstrated that decades of subtle but progressive change in macrophyte species composition are responsible for the apparently rapid community shift from macrophyte to algal dominance. Sayer et al. (2010a) stated:

This study highlights the enormous potential of palaeolimnology for recording the long-term dynamics of macrophytes and algal components of shallow lakes and for addressing key ecological questions from a longterm temporal perspective.

Such papers provide timely reminders about the importance of conserving and building on traditional investigative approaches to advance our understanding about ecological processes.

\section{Applied studies}

Paleolimnological methods are important tools for assessing changes in water quality and the introduction of contaminants to freshwater systems (Smol, 2008). The roles of paleolimnological studies in lake management and restoration programs in the European Union (Euro- 
pean Commission, 2000) were addressed recently in a special issue of Journal of Paleolimnology (Vol. 45, Issue 4), which focused on assessing the extent of human influence on European lakes. Contributions discussed the use of paleolimnology for quantifying human-influenced changes in freshwater ecosystems (Battarbee and Bennion, 2011), and for defining reference conditions and restoration targets (Bennion et al., 2011a). The use of paleolimnological methods for defining reference conditions and restoration targets for ecological and chemical conditions also was addressed.

Bennion et al. (2011b) examined total P inferences obtained from fossil diatom assemblages in nine lakes across Europe, and used modern analog matching methods to identify contemporary reference sites. The study lakes showed a range of slight to major floristic changes over time, for example with Lago Maggiore showing slight change. The improved aspect of this approach is that it utilized ecological information about species and соттиnities rather than reducing all biological data to a single chemical variable that had been predicted with a transfer function. Bindler et al. (2011) addressed metals reference conditions and concluded that in many instances, recent pre-industrial conditions are not an acceptable reference condition because significant anthropogenic metals contamination in Europe can date back to 500-2000 years ago, particularly for lead (Meriläinen et al., 2011). Cortizas et al. (2013) showed that the greatest $\mathrm{Pb}$ deposition in the Asturias region of northern Spain occurred during peak $\mathrm{Pb}$ production by the Romans c. 180-340 AD. Battarbee et al. (2011b) examined sediment cores from 121 low-alkalinity lakes in the UK and constructed a pre-acidification typology of lakes that showed 3 main clusters of water quality as indicated by diatom taxa. Rose et al. (2011) examined sediment accumulation rates of dated sediment cores from 207 European lakes to determine how accumulation rates changed in 25-year intervals. Study lakes were grouped with respect to alkalinity, altitude, depth, and area, and about $71 \%$ of the lakes demonstrated increased deposition rates over the last 100 years. Foster et al. (2011) used paleolimnological methods to estimate pre-disturbance deposition rates and sediment yield in order to quantify maximum feasible sediment reduction in rivers of England and Wales.

The cumulative findings of many such applied studies are increasingly being collected into databases that provide regional assessment of lake ecosystem changes, the timing of changes, and appropriate reference conditions (Battarbee et al., 2011a). These reference studies for EU lakes represent a well-coordinated effort to more effectively characterize lakes of the region, and they will lead to more appropriate lake management decisions. Similar well-coordinated efforts will be needed in the future for less studied areas.

\section{Transfer function models: improvements and qualifications}

Applied paleolimnological studies often rely on the creation and application of transfer functions to document historical changes in water quality. Transfer functions have been used widely in paleolimnology for decades, and they have been subject to many statistical advances. Recent studies have compared the performance of models and have examined factors that influence their reliability. Guilizzoni et al. (2011) examined total carotenoid-pigment concentrations in surface sediments of 28 Italian lakes and developed a predictive model for limnetic total $\mathrm{P}$ concentrations. They applied this model to sediment cores from four lakes, including Lago Maggiore, and compared $\mathrm{P}$ inferences with those obtained from diatombased models. The model based on total carotenoid pigments proved to be less subject to overestimation of limnetic total $\mathrm{P}$ than with diatom-based models, but in some lakes a significant macrophyte presence led to a decline in the pigment-based model performance.

Several studies examined the merits of single-site, local, and regional calibration sets for use in developing transfer functions. Kurek and Cwynar (2009) compared performance statistics of models based on these sampling strategies for estimating water depth from chironomids in sediments. They found that a site-specific model predicted modern water depth most accurately, whereas a local model overestimated and the regional model underestimated modern water depths. Engels et al. (2012) constructed a prediction model for water depth based on chironomids using site-specific and local calibration sets. The site-specific model showed the best performance statistics, but the calibration set for that model did not have modern analogs for some fossil samples. Consequently, the model based on the local calibration set was deemed most appropriate. These studies suggest that regional models, which are the most common type in use, might incorporate more sources of variance than are optimal for some prediction variables, or for some reconstruction scenarios.

Recent papers examined factors that affect transfer function performance. Telford and Birks (2011) demonstrated the importance of even distribution of calibration samples along environmental gradients of interest. They found that uneven distribution of samples can result in underestimation of error terms for portions of gradients that have gaps in representation, where species optima will be defined more poorly. The authors also proposed that valid models should explain more variance than is explained by random reconstructions. Heiri and Lotter (2010) studied the effects of taxonomic resolution on the performance of transfer functions for predicting mean Lateglacial July air temperature from chironomid assemblages in a sediment core from Hijkermeer in the Netherlands. Models based on genus level and below performed equally well, but models 
based on taxonomic levels above genus showed poor performance. These findings suggest that little improvement is gained from detailed chronomid taxonomic resolution, and that moderate levels of taxonomic resolution might provide adequate model performance with greater reassurance of taxonomic consistency among data sets.

Other studies examined the effects of count size on ecological variables, and how calibration set size can affect transfer function performance. Kurek et al. (2010) examined the effect of cladoceran count sizes on species richness and the relative abundances of dominant taxa, and they showed that counts of at least 70-100 individuals were required for accuracy. Reavie and Juggins (2011) explored the effects of training-set size on the performance of diatom-based inference models that predict limnetic total phosphorus. Training sets ranging from ten to several hundred samples from the Great lakes and Minnesota were examined. The authors concluded that at least 40 samples were needed to provide good model performance, and that 40 to 70 samples were required to produce calibration sets that did not leave an unacceptably large number of core samples without analogs.

\section{Limitations of univariate transfer functions, and new approaches}

More significant than model refinement, there has been growing concern about the accuracy and appropriateness of transfer functions that predict single variables. The relationships and variances of environmental factors in calibration sets typically differ from those in a sediment core from a single lake, and the effect of covariant influences on inferences can be complex and difficult to assess. Long-term changes in lakes often involve a variety of biological components and processes in both drivers and responses, so models that describe univariate change are conceptually limited. Investigators have long expressed concern that transfer functions neglect more complex aspects of lake response, and recent studies demonstrate the limitations of univariate models, and recommend better integrated approaches. Velle et al. (2010) studied midges as quantitative indicators of temperature change in Fennoscandia, and they examined factors that create bias in inferences. The authors pointed out that calibration sets tend to emphasize long gradients of interest but neglect other explanatory variables, some of which are likely to have interactions with the variable of interest, or might influence species' responses in threshold fashions. This study examined factors that affect the accuracy of inferences, and it recommended the use of multiple lines of evidence and autecological information for interpreting changes in lake ecosystems.

Several studies have focused on ways that single-variable quantitative inferences can be influenced by covariables, and on statistical procedures that are necessary to evaluate the models and species responses. Juggins (2013) showed that fundamental assumptions of transfer functions are not always met, and he used simulated training sets to demonstrate that covariables can lead to spurious inferences of change in variables of interest. In a subsequent paper, Juggins et al. (2013) examined training sets and diatombased calibration models that were developed for total P reconstructions. This study showed that DI-TP can track known changes in P loading, but the study reinforced qualifications about transfer functions by demonstrating limitations related to covariant effects, and the fact that some taxa were not responding to the variable of interest. Recent studies have presented innovative ways of addressing the fact that multiple rather than single structuring forces tend to influence changes in lake communities. Davidson et al. (2010a) showed that both submerged macrophyte abundance and zooplanktivorous fish influence cladoceran communities in shallow lakes of the UK and Denmark, and they developed a multivariate regression tree model that incorporated both explanatory variables. They observed six break points at which fish density and macrophyte abundance influenced significant changes in sub-fossil cladoceran assemblages. The model subsequently was applied to cladoceran assemblages in a sediment core from a shallow lake in England, and it accurately tracked changes in zooplanktivorous fish and macrophyte abundance over a 200-year period (Davidson et al. 2010b). Multivariate regression trees can be more effective at addressing the complex nature of ecosystem changes, and they avoid the often-violated assumption that factors influencing community response were univariate.

\section{Stable isotopes}

A recent review of advances in isotope geochemical applications in paleolimnology was presented by Leng and Henderson (2013). That review reported methodological improvements, including studies dealing with extraction and analyses of specific organic compounds for isotopic studies. In light of the thoroughness of that review, we mention but a few recent isotopic studies that were not covered in the paper.

$\delta^{18} \mathrm{O}$ offset of diatom silica from lake water was examined in Lake Annecy, France, to determine the influence of temperature on the offset (Crespin et al., 2010). Although the temperature coefficient slope was similar to that of other studies, offset differences apparently arose from differences in analytical methods or diagenetic effects, thus demonstrating a need for further study about influences on $\delta^{18} \mathrm{O}$ offsets prior to use of diatom silica in paleoclimatic reconstructions. Perga (2011) examined diagenetic changes in $\delta^{13} \mathrm{C}$ and $\delta^{15} \mathrm{~N}$ values of cladoceran exoskeletons using both laboratory and field experiments. She found that most changes took place during settling in the water column, but microbial breakdown of organic exoskeletons in sediments 
selectively liberated isotopically light $\mathrm{C}$ and $\mathrm{N}$ compounds. $\delta^{15} \mathrm{~N}$ values tracked seasonal changes in $\delta^{15} \mathrm{~N}$ of the living community, whereas $\delta^{13} \mathrm{C}$ values reflected the community during stratification, which suggests that $\mathrm{C}$ and $\mathrm{N}$ isotopes might be subject to different physiological processing within Cladocera. Apolinarska (2013) examined $\delta^{13} \mathrm{C}$ and $\delta^{18} \mathrm{O}$ values in shell carbonate of the invasive zebra mussel, Dreissena polymorpha, and compared values with those of waters from Lake Lednica, Poland where the shells were collected. Mean $\delta^{18} \mathrm{O}$ of shells was close to that of lake water, whereas substantially more offset was observed between $\delta^{13} \mathrm{C}$ of shells and lake water as a result of metabolic processes. Mean $\delta^{13} \mathrm{C}$ offset was constant, however, indicating that both $\delta^{13} \mathrm{C}$ and $\delta^{18} \mathrm{O}$ values of Dreissena polymorpha shells can be informative in paleoenvironmental reconstructions. Such studies highlight the importance of understanding how limnetic, post-depositional, and biotic processes contribute to variability in stable isotope values.

\section{Paleolimnological studies of regional and global climate of the past}

In recent years, regional representation of paleolimnological records has expanded considerably. More extensive paleolimnological records now exist for lakes in Asia including China, Russia, South America, New Zealand, Australia, the Arctic, and Antarctic. Lakes in very remote regions of the world have yielded important records for assessing global climate and environmental change (Catalan et al., 2013). We present summaries of some recent studies to highlight the importance of this work to our understanding about global climate changes.

Recent paleolimnological research in Central and South America has increased our understanding about the influence of El Nino/Southern Oscillation (ENSO) events on paleoclimate, and has helped document the effects of shifts in the position of the Intertropical Convergence Zone (ITCZ) on climate variability. Diatom $\delta^{18} \mathrm{O}$ isotope ratios from laminated sediments of a lake in Chile revealed patterns of dry to wet oscillations during the late glacial/Holocene transition (Hernandez et al., 2010). These patterns were related to solar activity and ENSO, as well as to changes in strength and position of the Bolivian High. A study of a highland glacial lake in Costa Rica used stable carbon isotopes of $n$-alkanes from terrestrial plants to examine aridity and rainfall associated with the migration of the ITCZ during the late Pleistocene and Holocene (Lane et al., 2011). Enters et al. (2010) used multiple lines of evidence (pollen, diatoms, $\mathrm{C} / \mathrm{N}$ ratios, biogenic silica and $\delta^{13} \mathrm{C}$ ) from laminated sediments in southeastern Brazil to describe Holocene precipitation patterns, and to assess how changes in terrestrial vegetation influenced erosion, nutrient inputs, and ultimately lake productivity. A 43-ka record of $\delta^{13} \mathrm{C}$ and $\delta^{18} \mathrm{O}$ values from ostracod shells in sediments of Lago Petén Itzá,
Guatemala documented linkages between neotropical climate and the influx of fresh water into the northern Atlantic and Gulf of Mexico due to meltwater events, and it provided evidence for a tropical megadrought between 19-15 ka BP (Escobar et al., 2012). Slate et al. (2013) documented how the southern migration of the ITCZ during the Holocene, together with volcanic and tectonic activity, influenced lake levels and trophic conditions in Lake Nicaragua. Recent studies in Asia investigated ENSO activity, the migration of the ITCZ, as well as the influence of the southern westerlies on regional climate. Rodysill et al. (2012) used calcite and $\delta^{13} \mathrm{C}$ of organic matter from a lake in Indonesia to describe decadal- and century-scale variation in wet and dry cycles, and their relationships to ENSO activity, Walker circulation patterns, and the southern migration of the ITCZ. An et al. (2013) used pollen records to describe changes in vegetation communities during the late Quaternary of NW China, and they presented evidence of regional variation in temperature and aridity during the Last Glacial Maximum (LGM). Diatom and isotope records from Lake Pupuke, a maar lake in New Zealand, documented variability in seasonality and precipitation during the late Quaternary and Holocene related to position and strength of the southern westerlies and to ENSO activity (Stephens et al. 2012b). In the remote southern Atlantic, a late Holocene diatom record from Tristan da Cunha revealed increases in precipitation and catchment erosion to shifts in the southern hemisphere westerlies (Holmgren SU et al., 2012). Diatom and phytolith records from Mozambique documented lateHolocene water-level fluctuations in an interdunal lake in response to changes in tropical and mid-latitude circulation patterns (Holmgren K et al., 2012).

Recent Arctic studies extended high-latitude paleoclimate records and described long-term patterns of climatic variation. A LGM record from Alaska based on chironomids, cladocera, pollen and geochemistry documented how increases in Alnus occurred in the watershed in response to temperature shifts, and how increased denitrification of soils led to greater nitrogen influx and lake productivity (Kaufman et al., 2012). Anderson et al. (2012) examined the late Pleistocene/early Holocene climate in SW Greenland using cores collected along a gradient from maritime to the dry interior. Mineral and carbonate accumulation records suggested that inland sites were more sensitive to variability in climate than coastal lakes. Luoto (2013) used chironomid assemblages to construct a regional temperature curve for the Little Ice Age in eastern and southern Finland. Lake records from Denmark recorded the $8.2 \mathrm{ka}$ cooling event and its influence on regional climate (Bjerring et al., 2013). In the lowlands of northern Germany, varved lake sediments revealed shifts in primary producer communities in response to variations in the North Atlantic Oscillation, solar activity, and temperature (Zahrer et al., 
2013). A sediment core from Lake Ohrid (Albania, Macedonia), the oldest extant lake in Europe, provided a 136-ka record that showed evidence of the evolution of the Mediterranean climate, and that detailed late glacial/interglacial changes in temperature and moisture (Vogel et al., 2010). Scussolini et al. (2011) used diatom, algal, and macrophyte remains in sediment cores to interpret the influence of the Little Ice Age and the Medieval Climate Anomaly on Lake Montcortes in the Iberian Peninsula. In North America, recent paleoclimate records extended our understanding about of regional variation in the Late Glacial/Holocene climate, and about the influence of the Medieval Warm Period on water availability within middle and western continental areas (Galloway et al., 2011). Recent studies also documented the occurrence and variability of the Pacific Decadal Oscillation and its influence on precipitation patterns (Kirby et al., 2010). Grain-size analysis of sediments from the northeastern US provided evidence about paleostorm activities during the Holocene, which were related to shifts in polar and tropical air-mass movements (Parris et al., 2010). A high-resolution late Pleistocene record from Nova Scotia documented climate variation during the Allerød warming, the Younger Dryas cooling, and the 8.2 ka cooling events (Lennox et al., 2010).

The expanded geographical distribution of paleolimnological records provides better understanding about mechanisms influencing global patterns of climate change. It also contributes to knowledge about regional and localized responses that will be important for forecasting the impact of future climate change on terrestrial and aquatic ecosystems.

\section{Studies reveal how climate change affects lake processes}

Many paleolimnological studies reveal information about how lake processes are altered by climate change and climate variability. Biological, chemical, and geological data recovered from undisturbed sedimentary sequences are useful for interpreting how changes in precipitation, temperature, and atmospheric circulation have impacted watersheds and lake basins.

Recent paleolimnological studies examined how climate changes affected hydrology and lake water levels (Lennox et al., 2010; Scussolini et al., 2011; Holmgren K et al., 2012; Turdryn et al., 2013). Lake evolution and development were examined in the context of changing climate regimes (Väliranta et al., 2011; Kaufman et al., 2012; Terasmaa et al., 2013). Recent studies reported changes in stratification and mixing patterns in response to climate change (Lennox et al., 2010; Kaufman et al., 2012; Gallaway et al., 2011; Heyng et al., 2012; Stephens et al., 2012a). Shifts between wet and dry climate cycles were shown to cause changes in erosion and sedimentation patterns (Vogel et al., 2010; Holmgren SU et al.,
2012; Bjerring et al., 2013). Studies examined the influence of climate on organic matter sources (Heyng et al., 2012), on primary productivity, and on eutrophication (Kaufman et al., 2012; Vogel et al., 2010; Stephens et al., 2012a; Scussolini et al., 2011; Zahner et al., 2013). Galloway et al. (2011) reported the effects of climate change on lake salinity in British Columbia based on diatom and pollen evidence. Paleoclimate studies in Antarctica reported variation in diatom succession in lakes that formed within the same glacial basin but were separated during the Holocene due to lowering water levels (Konfirst et al., 2011). Paleoclimate studies also documented short-term events such as paleofloods or paleostorms that had important influences on within-lake sedimentation and hydrology (Parris et al., 2010). Several European studies illustrate how paleolimnological research increases our understanding about the complex influences that climate has on lake communities, and how it can be used to predict aquatic responses to climate changes. Väliranta et al. (2011) used biological and geochemical evidence to examine the Holocene development of Lake Kipojärvi, a boreal lake in northern Finland. Changes in species richness in diatom and cladoceran communities were a response to reduced nutrient input from the watershed during midHolocene dry intervals, which led to decreased aquatic macrophyte abundance and diversity, and reduced habitat availability. Their study reinforces the importance of understanding lake and watershed linkages for predicting the impact of future climate change on lake ecosystems. Bjerring et al. (2013) described changes in Lake Sarup, Denmark in response to the 8.2 ka cooling event. Stable isotope records suggested that water levels decreased around $8.4 \mathrm{ka} \mathrm{BP}$, and inorganic matter accumulation rates increased because of erosion of marginal sediments, which led to increased turbidity, reduced nutrient influx, and changes in algal and macrophyte assemblages. Changes in community structure during this event were more strongly linked to hydrological changes than to temperature influences. Because climate models for Europe project both higher temperatures and greater winter precipitation in the future, lake managers will need to address ecosystem responses that are linked to hydrological changes. Nevalainen and Luoto (2012) examined the influence of post-Little Ice Age warming on chironomid and cladoceran communities in Lake Oberer Landschitzsee in the Austrian Alps. They documented complete species turnover in planktonic and benthic invertebrate communities in response to changes in benthic habitat quality, increased stratification, higher water temperatures, and productivity. One planktonic cladoceran species that typically is absent from alpine areas colonized the lake and became the dominant taxon in recent years. Land-use activities, such as pasturing, probably increased erosion and nutrient inputs during the late Holocene. The authors 
noted that land-use changes in response to warming in high-altitude habitats might be an indirect aspect of climate change that might further contribute to biotic shifts in lakes.

Paleolimnological studies in recent years have advanced our knowledge about how climate can affect lake hydrology, chemistry and biology, as well as watershed vegetation and soil processes. Holocene records often document both climate and anthropogenic influences, so they are useful for understanding how both factors work in conjunction to influence limnology. The emergent insights will prove important for better-informed lake management decisions in the future.

\section{Recent developments in dating sediment deposits}

Paleolimnological studies require good dating control to establish reliable chronologies of biological, environmental or climate change. ${ }^{210} \mathrm{~Pb},{ }^{137} \mathrm{Cs},{ }^{228} \mathrm{Ra}$, and ${ }^{14} \mathrm{C}$ are well-established radiometric tools that have been used widely to provide dates at depth in sedimentary profiles. Recent studies introduced the application of several additional dating methods. The ${ }^{32} \mathrm{Si}$ dating technique can be used to date sediments in the range of 20-1,000 years (Morgenstern et al., 2013). ${ }^{32} \mathrm{Si}$ is a cosmogenic isotope with a half-life of $\sim 144$ years that is incorporated into siliceous remains of organisms in lakes. Morgenstern et al. (2013) used ${ }^{32} \mathrm{Si}$ dating to establish a $\sim 1000$-yr chronology for a sediment core recovered from Lake Baikal, and established sedimentation rates that were not possible with other radiometric dating approaches. ${ }^{32} \mathrm{Si}$ has the potential to provide dates for time periods or for conditions that are not feasible for ${ }^{210} \mathrm{~Pb}$ and ${ }^{14} \mathrm{C}$ approaches. Optically stimulated luminescence (OSL) is another dating method that is becoming more widely used and available. Lee et al. (2011) applied the OSL dating approach to late Pleistocene sediments from Lake Ulaan in southern Mongolia, and they compared bulk radiocarbon and OSL dates for this sequence. While they found some agreement between radiocarbon and OSL dates, radiocarbon ages appeared too old in portions of their record, likely due to the introduction of old carbon from eolian processes. The authors suggested that OSL might be a superior dating approach for lake sediments that are influenced by detrital carbonate or old carbon of eolian origin.

${ }^{210} \mathrm{~Pb}$ models continue to be one of the most frequently used approaches for dating lake sediments, and for providing $\sim 100$-yr chronologies in studies that document recent environmental or climate changes. ${ }^{210} \mathrm{~Pb}$ models can not be used in all situations, however, especially where sedimentation is highly variable or episodic, and or where excess ${ }^{210} \mathrm{~Pb}$ might have been introduced from the watershed. Abril and Gharbi (2012) examined non-ideal deposition scenarios and identified factors that can adversely influence model performance and estimation of sedimentation rates. Abril
(2011) presented numerical approaches for using bulk density profiles to provide information about sedimentation rates, and to help validate ${ }^{210} \mathrm{~Pb}$ models.

\section{Paleolimnological lessons regarding aquatic food webs}

Fossil invertebrates, such as Cladocera or phantommidges, can be used to document trophic cascades, and to understand the influence of factors such as alkalinity, $\mathrm{pH}$, hypolimnetic oxygen concentrations, and macrophyte cover on trophic relationships. Fossil invertebrate remains reveal information about food-web structures, predatorprey dynamics, and they are useful for investigating the influence of invertebrate competition and predation on zooplankton size structure (Alexander and Hotchkiss, 2010). Invertebrate remains have been used to document the presence or absence of fish, often for specific fish families (e.g., Cyprinidae), to identify changes in fish planktivory, and to examine keystone fish predation (Palm et al., 2011; Tolonen et al., 2012; Twining and Post, 2013; Labaj et al., 2013). The use of these fossils to address aquatic trophic-web questions often relies on contemporary limnological information about zooplankton community structure in lakes with and without fish. For example, Tolonen et al. (2012) used modern and fossil phantom-midge data to derive Chaoborus-based regression models for small Swedish lakes, and to reconstruct past changes in fish biomass and density. Their study demonstrated the usefulness of certain chaoborid taxa as indicators of limnological conditions, such as basin morphometry and water transparency. Strock et al. (2013) used cladoceran ephippia, fossil sedimentary algal pigments, and fossil diatoms to understand the influence of white perch (Morone americana) introduction on oligotrophic lakes in Maine. They documented decreases in algal productivity and increases in zooplankton size that they attributed to trophic cascade interactions related to predation by a generalist fish species. Rawcliffe et al. (2010) utilized limnological and paleolimnological approaches to reconstruct historical food webs in shallow lakes. Using cladoceran surface-sediment assemblages, stable isotopes and gut contents from a variety of trophic levels within their study lakes, they described modern food web nodes and linkages, and calculated linkage density and connectance. They applied these modern analogs to core samples from a eutrophic lake and demonstrated that this approach could be used to document past food web community composition, to infer historic linkages, and to assess long-term changes in food web structure and function. Kurek et al. (2012) used fossil chironomids to assess pre-industrial hypolimnetic oxygen concentrations in a series of lakes in Nova Scotia, Canada to determine if there was evidence of declining water quality that might have impacted brook trout (Salvelinus fontinalis) populations, as suggested by contemporary limnological data. Fossil data showed evidence of stable chironomid assemblages since pre-indus- 
trial times, and indicated that there had not been significant change in hypolimnetic oxygen concentrations.

These studies highlight the importance of using paleolimnological data in conjunction with modern limnological sampling to address concerns about changes in water quality and food web structure.

\section{Novel applications of paleolimnological records to population-, community-, and ecosystem-level questions}

As paleolimnological techniques are refined, they are being applied in interesting and novel ways. Brooks et al. (2012) compared chironomids, diatom-inferred limnetic total $\mathrm{P}$ concentrations, sedimentary algal pigments, and climate data with past census data for Podiceps auritus (Slovonian grebe) in an attempt to understand the causes for recent changes in bird population sizes. Chironomid abundance varied with lake productivity, and the results suggested that fluctuations in breeding success might be linked to resource availability for Grebe chicks.

Coprophilous fungal spores in lake sediments have been used to document historic changes in livestock abundance in watersheds. Etienne et al. (2013) examined fossil spores in a series of sediment cores from a lake in the French Alps and compared spore data to historic records of sheep density within the surrounding watershed. Their results suggested that coprophilous fungal spores can track changes in livestock abundance, but they caution that the application of this method is sensitive to core site location. Fungi also have been used as evidence of episodic weather events. Van Geel et al. (2013) used ascospores from Kretzschimaria deusta, a parasitic fungus of beech trees (Fagus sylvatica), to document discrete rainfall events in late-Holocene laminated sediments from Germany. They hypothesized that the ascospores, although generally not abundant in sediments, increased at discrete points in the sediment record because of stormwater runoff and winds that introduced material from the surrounding forested watershed into the lake.

Fossil algae, particularly diatoms and chrysophytes, have long been used to document changes in water quality and lake habitat availability. Recent studies of Pediastrum spp. evaluated their usefulness for interpreting past changes in the water level of lowland tropical lakes. Whitney and Mayle (2012) examined open-water and macrophyte-associated Pediastrum species in sediments of a lake within the Pantanal of Brazil, and they suggested that Pediastrum community-level shifts might be useful for documenting changes in precipitation and lake-levels. Weckstrom et al. (2010) used Pediastrum species composition in sediment cores to interpret environmental changes in subarctic lakes. Their study noted that Pediastrum abundance was best explained by dissolved organic carbon (DOC) and pH variation. Nevalainen et al. (2011) examined the influence of environmental stresses, such as lake acidification and cultural eutrophication, on reproduction in chydorids (Cladocera) in several Finnish lakes. Sedimented ephippia were used as evidence of past sexual reproduction, and related to increasing aluminum from atmospheric pollution and to inferred limnetic total P concentrations. Sexual reproduction increased as water quality declined, and the authors concluded that environmental stress increases sexual reproduction because it promotes genetic heterogeneity and population persistence.

Waterfowl populations serve as a source for nutrients in lakes, and they can impact trophic relationships and macrophyte community structure. Reflectance spectroscopy has been used recently to infer historic bird population sizes by analysis of the spectral signature of bird guano in sediments. Liu et al. (2011) used spectral analysis to reconstruct penguin population sizes from evidence in sediment cores that represented a 3000-yr record from Antarctic lakes. Decreased population sizes were related to periods of low precipitation and temperature. This approach might prove increasingly useful for studying lakes that receive significant guano inputs, and for relating fluctuations in bird populations to changes in lake productivity and trophic structure.

Fossils from lake sediments have been used to examine temporal patterns in coevolution between host and parasites. In a unique study, Decaestecker et al. (2007) recovered dormant Daphnia magna eggs from different depths in a sediment core from a shallow pond in Belgium. The authors hatched Daphnia clones, and isolated a bacterial endoparasite from the clones. They exposed Daphnia clones from different time periods to endoparasites that were recovered from hosts at different points in time. Infection was highest for hosts exposed to contemporary parasites, but was lower for parasites isolated from past and future populations. The authors suggest that parasites were closely tracking contemporary hosts, and rapidly evolving to successfully infect host populations. These results are consistent with the concept of antagonistic coevolution, and provide empirical evidence for the Red Queen hypothesis, and for reciprocal evolutionary dynamics.

\section{The use of genetic markers in sediment studies}

Several recent studies have explored the use of sedimented genetic markers as indicators of change in communities or in single species over time. Epp et al. (2010) examined DNA molecular evidence for tropical rotifers in the genus Brachionus in a sediment core from Lake Sonachi, Kenya and from surface sediments of other lakes in the East African lake System. This study showed that despite short-term environmental variation in this lake and presumed population fluctuations, one haplotype of Branchionus dominated over a long-term period, probably as a result of repeated reintroduction from resting stages in 
surface sediments. Subsequent transitions were associated with introduction of volcanic ash, and with low water levels in the 1940s. Fernandez-Carazo et al. (2013) examined pigments and genetic markers of cyanobacteria in sediment cores from two maritime lakes in Antarctica. This study showed the utility of fossil DNA for reconstructing long-term patterns of cyanobacterial community composition. The study also provided caveats that markers can be influenced by selective degradation, which can vary by species or genus, or be influenced by the presence of akinetes or cellular enzymes.

Copepods are often prominent members of the zooplankton in lakes, but they do not leave fossilized exoskeletons in sediments. Makino et al. (2013) used a novel approach to examine historical changes in copepod communities in Japan. The authors extracted ribosomal DNA from calanoid copepod diapausing eggs, and created a 28S rDNA regional sequence library. This study demonstrated that the $n c 28 \mathrm{~S}$ region could be used as a marker for distinguishing different calanoid species in surface sediment from lakes.

\section{More limnological studies are needed as the range of paleolimnological research expands}

Paleolimological research is expanding to remote lake sites, and into geographical regions that possess limited limnological records. Climate-change research, among other factors, has provided stimulus for greater geographical coverage. Many remote lakes, such as those on ocean islands or in mountainous regions, lack detailed limnological studies. Remote lakes are sometimes visited on one or two occasions for sediment coring, and some lakes have been sampled only once or sporadically for aquatic organisms or water chemistry. With such paucity of information, little might be known about local lake processes, or about factors that influence how processes change on a seasonal or annual basis. Edward S. Deevey, Jr. pointed out during the discussion following the Smol (1990) review for the Istituto Italiano di Idrobiologia di Pallanza Jubilee Conference that most limnologists work in temperate areas, and that is still true today. In doing so, investigators can carry biases to other areas about how lake ecosystems are structured and function.

Factors such as biogeography and climate can be responsible for differences in lake processes and sediment records among regions. As an example that is familiar to the present authors, shallow subtropical lakes of Florida and tropical lakes of central and South America have biological seasonal cycles, mixing patterns, heat budgets, karst hydrological influences, and deposition patterns that vary considerably from northern lakes, and taxa might have different ecological niches and physiological constraints than they do in temperate regions. These differences have important influences on aquatic succession, seasonal events, community structure, as well as biogeochemical cycling, and the lakes might not be subject to the same processes and responses that are expected by investigators from temperate regions. Regional differences can present a challenge when investigators interpret sediment records, particularly if preconceived ideas about processes are brought to new study areas. Consequently, more limnological research in understudied areas will help paleolimnologists interpret changes in sediment records more effectively.

\section{CONCLUSIONS}

Recent paleolimnological studies call for greater integration of paleolimnology with modern ecological and experimental studies. More ecological information is needed to accurately interpret paleolimnological results, and paleolimnology provides time perspectives that enhance contemporary studies. There is considerable need in both the limnological and paleolimnological disciplines to renew interest in aspects of theoretical ecology, including topics related to food webs, population and community concepts, and ecosystem-level questions. Recent investigations have focused on how to construct better calibration sets and transfer functions, but there is growing consensus that it is important to consider ecological information from several lines of evidence rather than to reduce all information to a univariate water-quality inference. This is particularly important when defining reference conditions, because inappropriate restoration targets might prove unachievable. Paleolimnological studies increasingly show that lake responses to climatic and human influences are complex, multidimensional, and often indirectly mediated through watershed processes. In some instances, changes have been more profound than what might be anticipated from an apparently simple driver, and some lakes fail to recover fully. Insights about responses to future climate change will need to be projected into lake management decisions. As paleolimnological studies expand in range and intensity, the geographic range is sometimes expanding faster than adequate understanding about limnology, particularly on remote ocean islands, in the subtropics and tropics, and in high-altitude and high-latitude regions. We see the need for additional research as both a challenge and opportunity for the field of limnology.

\section{ACKNOWLEDGMENTS}

We thank two anonymous reviewers for suggestions that helped us to better focus the manuscript.

\section{REFERENCES}

Abril JM, 2011. Could bulk density profiles provide information about recent sedimentation rates? J. Paleolimnol. 46:173-186. Abril JM, Gharbi F, 2012. Radiometric dating of recent sedi- 
ments: beyond the boundary conditions. J. Paleolimnol. 48:449-460.

Alexander ML, Hotchkiss SC, 2010. Bosmina remains in lake sediment as indicators of zooplankton community composition. J. Paleolimnol. 43:51-59.

An CB, Tao SC, Zhao J, Chen FH, Lv Y, Dong W, Li H, Zhao Y, Jin M, Wang Z, 2013. Late Quaternary (30.7-9.0 cal ka BP) vegetation history in Central Asia inferred from pollen records of Lake Balikun, northwest China. J. Paleolimnol. 49:145-154.

Anderson NJ, Liversidge AC, McGowan S, Jones MD, 2012. Lake and catchment response to Holocene environmental change: spatial variability along a climate gradient in southwest Greenland. J. Paleolimnol. 48:209-222.

Apolinarska K, 2013. Stable isotope compositions of recent Dreissena polymorpha (Pallas) shells: paleoenvironmental implications. J. Paleolimnol. 50:355-364.

Battarbee RW, Bennion H, 2011. Palaeolimnology and its developing role in assessing the history and extent of human impact on lake ecosystems. J. Paleolimnol. 45:399-404.

Battarbee RW, Simpson GL, Bennion H, 2011a. A reference typology of low alkalinity lakes in the UK based on pre-acidification diatom assemblages from lake sediment cores. J. Paleolimnol. 45:489-505.

Battarbee RW, Simpson GL, Bennion H, Curtis C, 2011b. A reference typology of low alkalinity lakes in the UK based on pre-acidification diatom assemblages from lake sediment cores. J. Paleolimnol. 45:405-414.

Bennion H, Battarbee RW, Sayer CD, Simpson GL, Davidson TA, 2011a. Defining reference conditions and restoration targets for lake ecosystems using palaeolimnology: a synthesis. J. Paleolimnol. 45:533- 544.

Bennion H, Simpson GL, Anderson NJ, Clarke G, Dong X, Hobæk A, Guilizzoni P, Marchetto P, Sayer CD, Thies H, Tolotti M, 2011b. Defining ecological and chemical reference conditions and restoration targets for nine European lakes. J. Paleolimnol. 45:415-431.

Bindler B, Rydberg J, Renberg I, 2011. Establishing natural sediment reference conditions for metals and the legacy of longrange and local pollution on lakes in Europe. J. Paleolimnol. 45: 519-531.

Bjerring R, Olsen J, Jeppesen, E, Buchardt B, Heinemeier J, McGowan S, Leavitt PR, Enevold R, Odgaard BV, 2013. Climatedriven changes in water level: a decadal scale multi-proxy study recording the 8.2-ka event and ecosystem responses in Lake Sarup (Denmark). J. Paleolimnol. 49:267-285.

Brooks SJ, Jones VJ, Telford RJ, Appleby PG, Watson E, McGowan S, Benn S, 2012. Population trends in the Slavonian grebe Podiceps auritus (L.) and Chironomidae (Diptera) at a Scottish loch. J. Paleolimnol. 47:631-644.

Catalan J, Pla-Rabés S, Wolfe AP, Smol JP, Rühland KM, Anderson J, Kopácek J, Stuchlík E, Schmidt R, Koinig KA, Camarero L, Flower RJ, Heiri O, Kamenik C, Korhola A, Leavitt PR, Psenner R, Renberg I, 2013. Global change revealed by palaeolimnological records from remote lakes: a review. J. Paleolimnol 49:513-535.

Cohen AS, 2003. Paleolimnology: the history and evolution of lake systems. Oxford University Press: $528 \mathrm{pp}$.

Cortizas AM, López-Merino L, Bindler R, Mighall T, Kylander $\mathrm{M}, 2013$. Atmospheric $\mathrm{Pb}$ pollution in $\mathrm{N}$ Iberia during the late Iron Age/Roman times reconstructed using the high-resolution record of La Molina mire (Asturias, Spain). J. Paleolimnol. 50:71-86.

Crespin J, Sylvestre F, Alexandre A, Sonzogni C, Pailles C, Perga ME, 2010. Re-examination of the temperature-dependent relationship between delta ${ }^{18} \mathrm{O}$ (diatoms) and delta ${ }^{18} \mathrm{O}$ (lake water) and implications for paleoclimate inferences. J. Paleolimnol. 44:547-557.

Davidson TA, Sayer CD, Perrow M, Bramm M, Jeppesen E, 2010a. The simultaneous inference of zooplanktivorous fish and macrophyte density from sub-fossil cladoceran assemblages: a multivariate regression tree approach. Freshwater Biology 55:546-564.

Davidson TA, Sayer CD, Langdon PG, Burgess A, Jackson M, 2010b. Inferring past zooplanktivorous fish and macrophyte density in a shallow lake: application of a new regression tree model. Freshwater Biology 55:584-599.

Decaestecker E, Gaba S, Raeymaekers JAM, Stoks R, Van Kerckhoven L, Ebert D, De Meester L, 2007. Host-parasite 'Red Queen' dynamics archived in pond sediment. Nature 450:870-874.

Engels S, Cwynar LC, Rees ABH, Shuman BN, 2012. Chironomid-based water depth reconstructions: an independent evaluation of site-specific and local inference models. J. Paleolimnol. 48:693-709.

Enters D, Behling H, Mayr C, Dupont L, Zolitschka B, 2010. Holocene environmental dynamics of south-eastern Brazil recorded in laminated sediments of Lago Aleixo. J. Paleolimnol. 44:265-277.

Epp LS, Stoof KR, Trauth MH, Tiedemann R, 2010. Historical genetics on a sediment core from a Kenyan lake: intraspecific genotype turnover in a tropical rotifer is related to past environmental changes. J. Paleolimnol. 43:939-954.

Escobar J, Hodell DA, Brenner M, Curtis JH, Gilli A, Mueller A, Anselmetti FS, Ariztegui D, Grzesik DA, Pérez L, Schwalb A, Guilderson TP, 2012. A 43-ka record of paleoenvironmental change in the Central American lowlands inferred from stable isotopes of lacustrine ostracods. Quaternary Sci. Rev. 37:92-104.

Etienne D, Wilhelm B, Sabatier P, Reyss JL, Arnaud F, 2013. Influence of sample location and livestock numbers on Sporormiella concentrations and accumulation rates in surface sediments of Lake Allos, French Alps. J. Paleolimnol. 49:117-127.

European Commission, 2000. Directive 2000/60/EC of the European Parliament and of the Council establishing a framework for the community action in the field of water policy. In: Official Journal, L 327/2000, p. 1-73.

Fernandez-Carazo R, Verleyen E, Hodgson DA, Roberts SJ, Waleron K, Vyverman W, Wilmotte A, 2013. Late Holocene changes in cyanobacterial community structure in maritime Antarctic lakes. J. Paleolimnol. 50:15-31.

Foster IDL, Collins AL, Naden PS, Sear DA, Jones JI, Zhang Y, 2011. The potential for paleolimnology to determine historic sediment delivery to rivers. J. Paleolimnol. 45:287-306.

Galloway JM, Lenny AM, Cumming BF, 2011. Hydrological change in the central interior of British Columbia, Canada: diatom and pollen evidence of millennial-to-centennial scale change over the Holocene. J. Paleolimnol. 45:183-197.

Guilizzoni P, Marchetto A, Lami A, Gerli S, Musazzi S, 2011. 
Use of sedimentary pigments to infer past phosphorus concentration in lakes. J. Paleolimnol. 45:433-445.

Heiri O, Lotter AF, 2010. How does taxonomic resolution affect chironomid-based temperature reconstruction? J. Paleolimnol. 44:589-601.

Hernandez A, Giralt S, Bao R, Saez A, Leng MJ, Barker PA, 2010. ENSO and solar activity signals from oxygen isotopes in diatom silica during late glacial-Holocene transition in Central Andes (18 ${ }^{\circ}$ S). J. Paleolimnol. 44:413-429.

Heyng AM, Mayr C, Lücke A, Striewski B, Wastegård S, Wissel H, 2012. Environmental changes in northern New Zealand since the Middle Holocene inferred from stable isotope records $\left(\delta^{15} \mathrm{~N}, \delta^{13} \mathrm{C}\right)$ of Lake Pupuke. J. Paleolimnol. 48:351-366.

Holmgren K, Risbery J, Freudendahl J, Achimo M, Ekblom A, Mugabe J, Norstrom E, Sitoe S, 2012. Water-level variation in Lake Nhauhache, Mozambique, during the last 2,300 years. J. Paleolimnol. 48:311-322.

Holmgren SU, Ljung K, Björck S, 2012. Late Holocene environmental history on Tristan da Cunha, South Atlantic, based on diatom floristic changes and geochemistry in sediments of a volcanic crater lake. J. Paleolimnol. 47:221-232.

Juggins S, 2013. Quantitative reconstructions in palaeolimnology: new paradigm or sick science? Quaternary Sci. Rev. 64:20-32.

Juggins S, Anderson NJ, Ramstack Hobbs JM, Heathcote AJ, 2013. Reconstructing epilimnetic total phosphorus using diatoms: statistical and ecological constraints. J. Paleolimnol. 49:373-390.

Kaufman DS, Axford Y, Anderson RS, Lamoureux SF, Schindler DE, Walker IR, Werner A, 2012. A multi-proxy record of the Last Glacial Maxium and last 14,500 years of paleoenvironmental change at Lone Spruce Pond, southwestern Alaska. J. Paleolimnol. 48:9-26.

Kirby ME, Lund SP, Patterson WP, Anderson MA, Bird BW, Ivanovici L, Monarrez P, Nielsen, 2010. A Holocene record of Pacific Decadal Oscillation (PDO)-related hydrologic variability in Southern California (Lake Elsinore, CA). J. Paleolimnol. 44:819-839.

Konfirst MA, Sjunneskog C, Scherer, RP, Doran PT, 2011. A diatom record of environmental change in Fryxell Basin, Taylor Valley, Antarctica, late Pleistocene. J. Paleolimnol. 46:257-272.

Kurek J, Cwynar LC, 2009. The potential of site-specific and local chironomid-based inference models for reconstructing past lake levels. J. Paleolimnol. 42:37-50.

Kurek J, Korosi JB, Jeziorski A, Smol JP, 2010. Establishing reliable minimum count sizes for cladoceran subfossils sampled from lake sediments. J. Paleolimnol. 44: 603-612.

Kurek J, Lawlor L, Cumming BF, Smol JP, 2012. Long-term oxygen conditions assessed using chironomid assemblages in brook trout lakes from Nova Scotia, Canada. Lake Reserv. Manage. 28:177-188.

Labaj AL, Kurek J, Weeber RC, Smol JP, 2013. Long-term changes in invertebrate size structure and composition in a boreal headwater lake with a known minnow introduction. J. Limnol. 72:e17.

Lane CS, Horn SP, Mora CI, Orvis KH, Finkelstein DB, 2011. Sedimentary stable carbon isotope evidence of late Quaternary vegetation and climate change in highland Costa Rica. J. Paleolimnol. 45:323-338.

Lee MK, Lee YI, Lim HS, Lee JI, Choi JH, Yoon HI, 2011.
Comparison of radiocarbon and OSL dating methods for a Late Quaternary sediment core from Lake Ulaan, Mongolia. J. Paleolimnol. 45:127-135.

Leng MJ, Henderson ACG, 2013. Recent advances in isotopes as palaeolimnological proxies. J. Paleolimnol. 49:481-496.

Lennox B, Spooner I, Jull T, Patterson WP, 2010. Post-glacial climate change and its effect on a shallow dimictic lake in Nova Scotia, Canada. J. Paleolimnol. 43:15-27.

Liu X, Sun J, Sun L, Liu W, Wang Y, 2011. Reflectance spectroscopy: a new approach for reconstructing penguin population size from Antarctic ornithogenic sediments. J. Paleolimnol. 45:213-222.

Luoto TP, 2013. How cold was the Little Ice Age? A proxybased reconstruction from Finland applying modern analogues of fossil midge assemblages. Environ. Earth Sci. 68:1321-1329.

Makino W, Ohtsuki H, Urabe J, 2013. Finding copepod footprints: a protocol for molecular identification of diapausing eggs in lake sediments. Limnology 14:269-282.

Meriläinen JJ, Kustula V, Witick A, 2011. Lead pollution history from $256 \mathrm{BC}$ to $\mathrm{AD} 2005$ inferred from the $\mathrm{Pb}$ isotope ratio $\left({ }^{206} \mathrm{~Pb} /{ }^{207} \mathrm{~Pb}\right)$ in a varve record of Lake Korttajarvi in Finland. J. Paleolimnol. 45:1-8.

Morgenstern U, Ditchburn RG, Vologina EG, Sturm M, 2013. ${ }^{32} \mathrm{Si}$ dating of sediments from Lake Baikal. J. Paleolimnol. 50:345-352.

Nevalainen L, Luoto TP, Levine S, Manca M, 2011. Paleolimnological evidence for increased sexual reproduction in chydorids (Chydoridae, Cladocera) under environmental stress. J. Limnol. 70:255-262.

Nevalainen L, Luoto TP, 2012. Faunal (Chironomidae, Cladocera) responses to post-Little Ice Age climate warming in the high Austrian Alps. J. Paleolimnol. 48:711-724.

Palm F, El-Daoushy F, Svensson JE, 2011. Fragmented subfossil Chaoborus mandibles reveal periods of cyprinid presence in lake histories. J. Paleolimnol. 45:101-113.

Parris AS, Bierman PR, Noren AJ, Prins MA, Lini A, 2010. Holocene paleostorms identified by particle size signatures in lake sediments from the northeastern United States. J. Paleolimnol. 43:29-49.

Pennington W, 1981. Records of a lake's life in time: the sediments. Hydrobiologia 79:197-219.

Perga ME, 2011. Taphonomic and early diagenetic effects on the $\mathrm{C}$ and $\mathrm{N}$ stable isotope composition of cladoceran remains: implications for paleoecological studies. J. Paleolimnol. 46:203-213.

Pienitz R, Lotter A, Newman L, Kiefer T, 2009. Advances in paleolimnology. PAGES News 17:90-136.

Rawcliffe R, Sayer CD, Woodward G, Grey J, Davidson TA, Jones JI, 2010. Back to the future: using palaeolimnology to infer long-term changes in shallow lake food webs. Freshwater Biology 55:600-613.

Reavie, ED, Juggins S, 2011. Exploration of sample size and diatom-based indicator performance in three North American phosphorus training sets. Aquat. Ecol. 45:529-538.

Rodysill JR, Russell JM, Bijaksana S, Brown ET, Safiuddin LO, Eggermont H, 2012. A paleolimnological record of rainfall and drought from East Java, Indonesia during the last 1,400 years. J. Paleolimnol. 47:125-139.

Rose NL, Morley D, Appleby PG, Battarbee RW, Alliksaar T, 
Guilizzoni P, Jeppesen E, Korhola A, Punning JM, 2011. Sediment accumulation rates in European lakes since AD 1850: trends, reference conditions and exceedence. J. Paleolimnol. 45:447-468.

Sayer CD, Burgess A, Kari K, Davidson TA, Peglar S, Yang HD, Rose N, 2010a. Long-term dynamics of submerged macrophytes and algae in a small and shallow, eutrophic lake: implications for the stability of macrophyte-dominance. Freshwater Biol. 55:565-583.

Sayer CD, Davidson TA, Jones JI, 2010b. Seasonal dynamics of macrophytes and phytoplankton in shallow lakes: a eutrophication-driven pathway from plants to plankton? Freshwater Biol. 55:500-513.

Sayer CD, Davidson TA, Jones JI, Langdon PG, 2010c. Combining contemporary ecology and palaeolimnology to understand shallow lake ecosystem change. Freshwater Biol. 55:487-499.

Scheffer M, Hosper SH, Meijer ML, Moss B, Jeppesen E, 1993. Alternative equilibria in shallow lakes. Trends Ecol. Evol. 8:275-279.

Scussolini P, Vegas-Valarrúbia T, Rull V, Corella JP, ValeroGarcés B, Gomà J, 2011. Middle and late Holocene climate change and human impact inferred from diatoms, algae and aquatic macrophyte pollen in sediments from Lake Montcortès (NE Iberian Peninsula). J. Paleolimnol. 46:369-385.

Slate JE, Johnson TC, Moore TC, 2013. Impact of preColumbian agriculture, climate change, and tectonic activity inferred from a 5,700-year paleolimnological record from Lake Nicaragua. J. Paleolimnol. 50:139-149.

Smol J, 1990. Paleolimnology: recent advances and future challenges. In: R. de Bernardi, G. Giussani and L. Barbanti (eds.) Scientific perspectives in theoretical and applied limnology. Mem. Ist. Ital. Idrobiol. 47:253-276.

Smol JP, 2008. Pollution of lakes and rivers: a paleoenvironmental perspective, 2nd edition. Blackwell Publishing: 383 pp.

Smol JP, 2010. Paleolimnology, p. 56-64. In: G.E. Likens (ed.) Lake ecosystem ecology: a global perspective. Elsevier, Amsterdam.

Stephens T, Atkin D, Augustinus P, Shane P, Lorrey A, StreetPerrott A, Nilsson A, Snowball I, 2012a. A late glacial Antarctic climate teleconnection and variable Holocene seasonality at Lake Pupuke, Auckland, New Zealand. J. Paleolimnol. 48:785-800.

Stephens T, Atkin D, Cochran U, Augustinus P, Reid M, Lorrey A, Shane P, Street-Perrott A, 2012b. A diatom-inferred record of reduced effective precipitation during the Last Glacial Coldest Phase (28.8-18.0 cal kyr BP) and increasing Holocene seasonality at Lake Pupuke, Auckland, New Zealand. J. Paleolimnol. 48:801-817.
Strock KE, Saros JE, Simon KS, McGowan S, Kinnison MT, 2013. Cascading effects of generalist fish introduction in oligotrophic lakes. Hydrobiologia 711:99-113.

Telford RJ, Birks HJB, 2011. A novel method for assessing the statistical significance of quantitative reconstructions inferred from biotic assemblages. Quaternary Sci. Rev. 30:1272-1278.

Terasmaa J, Puusepp L, Marzecová A, Vandel E, Vaasma T, Koff T, 2013. Natural and human-induced environmental changes in Eastern Europe during the Holocene: a multi-proxy palaeolimnological study of a small Latvian lake in a humid temperate zone. J. Paleolimnol. 49:663-678.

Tolonen KT, Brodersen KP, Kleisborg TA, Holmgren K, Dahlberg M, Hamerlik L, Hämäläinen H, 2012. Phantom midge-based models for inferring past fish abundances. J. Paleolimnol. 47:531-547.

Tudryn A, Tucholka P, Özgûr N, Gibert E, Elitok O, Kamaci Z, Massault M, Poisson A, Platevoet, B, 2013. A 2300-year record of environmental change from SW Anatolia, Lake Burdur, Turkey. J. Paleolimnol. 49:647-662.

Twining CW, Post DW, 2013. Cladoceran remains reveal presence of a keystone size-selective planktivore. J. Paleolimnol. 49:253-266

Väliranta M, Weckström J, Siltonen S, Seppä H, Alkio J, Juutinen S, Tuittila E-S, 2011. Holocene aquatic ecosystem change in the boreal vegetation zone of northern Finland. J. Paleolimnol. 45:339-352.

van Geel B, Engels S, Martin-Puertas C, Brauer A, 2013. Ascospores of the parasitic fungus Kretzschmaria deusta as rainstorm indicators during a late Holocene beech-forest phase around Lake Meerfelder Maar, Germany. J. Paleolimnol. 50:33-40.

Velle G, Brodersen KP, Birks HJB, Willassen E, 2010. Midges as quantitative temperature indicator species: Lessons for palaeoecology. Holocene 20:986-1002.

Vogel H, Wagner B, Zanchetta G, Sulpizio R, Rosén, 2010. A paleoclimate record with tephrochronological age control for the last glacial-interglacial cycle from Lake Ohrid, Albania and Macedonia. J. Paleolimnol. 44:295-310.

Weckström K, Weckström J, Yliniemi LM, Korhola A, 2010. The ecology of Pediastrum (Chlorophyceae) in subarctic lakes and their potential as paleobioindicators. J. Paleolimnol. 43:61-73.

Whitney BS, Mayle FE, 2012. Pediastrum species as potential indicators of lake-level change in tropical South America. J. Paleolimol. 47:601-615.

Zahrer J, Drebrodt S, Brauer A, 2013. Evidence of the North Atlantic Oscillation in varve composition and diatom assemblages from recent, annually laminated sediments of Lake Belau, northern Germany. J. Paleolimnol. 50:231-244. 